\title{
Autism and Food Selectivity- Mini Review
}

\author{
Roberto Carlos Mourão Pinho* \\ Faculty Dentistry, Federal University of Pernambuco UFPE, Brazil
}

*Corresponding author: Roberto Carlos Mourão Pinho, Faculty Dentistry, Federal University of Pernambuco UFPE, Brazil

Keywords: Autism; Mental Retardation; Physical Appearance; Pioneering Studies; Environment; Hyperresponsive; Ritualistic Behaviors; Psychiatrist; Disorders; Cognitive Skills

\section{Introduction}

The label "autism" has become one of the most important linguistic and conceptual creations in medical and psychological nomenclature, and has two names linked to pioneering studies: Austrian pediatrician Hans Asperger and Austrian psychiatrist Leo Kanner. Seventy years have passed since the publication of Asperger's text on autism (1944), Kanner's article (1943) had been known since its publication. Asperger was totally ignored until 1976 when English psychiatrist Lorna Wing published an article summarizing the work [1]. Kanner (1943), who first described and named early childhood autism, believed it was a distinct entity to be clearly distinguished from mental retardation, but there are many people who would argue that the two cannot be separated [2].

Autism and Asperger's syndrome [3-5] are best known among invasive developmental disorders (PDD), a family of conditions marked by the early onset of delays and deviations in the development of social, communicative and cognitive skills. too many skills [6]. The first reports were made in 1943 by Leo Kanner, who first described 11 cases of what he called autistic affective contact disorders [7] as a condition with very specific behavioral characteristics, such as: disturbances of affective relationships. with the environment, extreme autistic loneliness, inability to use language for communication, presence of good cognitive potentialities, apparently normal physical appearance, ritualistic behaviors, early onset and predominant incidence in males.

Knickerbocker proposed that oral sensitivity, which is common in children with ASD, may be another example of a sensory system that is not only hyperresponsive to oral input, but also has a deficit in the modulation capacity of a varied sensory information input [8].

Oral hyperresponsiveness is more common in children with ASD than in children with typical development. Children with oral hyperresponsiveness are described as picky eaters, eat few vegetables and fruits, refuse to eat the same meal as their family, refuse to try and have aversion to certain tastes, textures and smells, do not like foods with low temperatures. or tall [9]. Parents of children with ASD often report that their children have a very restricted diet, with limited and limited food selection and acceptance and may be restricted to five foods [10].

In several of the studies analyzed by the authors, reports of food-based refusal of food have been identified, and difficulties in ingesting certain food textures have been attributed to changes in sensory processing or may be indicative of oro-motor difficulties, as well., sensory or oromotor changes may contribute to food refusal, with difficulty in chewing food or tolerating texture mix [11].

\section{References}

1. Dias S (2015) Asperger e sua síndrome em 1944 e na atualidade. Rev Latinoam Psicopat Fund 18(2): 307-313.

2. Wing L (1974) Language development and autistic behaviour in severely mentally retarded children. Proc R Soc Med 67(10): 1031-1032.

3. Wing L (1973) Concepts of autism: a review. Invited comments. Aust Paediatr J 9(5): 246-247.

4. Wing L, Wing JK (1971) Multiple impairments in early childhood autism. J Autism Child Schizophr 1(3): 256-266.

5. Wing L (1969) The handicaps of autistic children--a comparative study. J Child Psychol Psychiatry 10(1): 1-40.

6. Klin A (2006) Autismo e síndrome de Asperger: uma visão geral Autism and Asperger syndrome: an overview. Rev Bras Psiquiatr 28(Supl I): S3S11.

7. Kanner L (1943) Autistic disturbances of affective contact. Nerv Child New York2: 217-250.

8. Knickerbocker BM (1980) A holistic approach to learning disabilities. Thorofare, C.B. Slack Publisher, NJ, USA. 
9. Dunn W, Feldman DE, Gisel E \& Nadon G (2011) Association of Sensory Processing and Eating Problems in Children with Autism Spectrum Disorders. Autism Research and Treatment.

10. Bandini LG, Cermak SA \& Curtin C (2010) Food Selectivity and Sensory Sensitivity in Children with Autism Spectrum Disorders. Journal of the American Dietetic Association 110: 238-246.

\section{(c) $(\underset{\mathrm{BY}}{ }$ \\ This work is licensed under Creative \\ Commons Attribution 4.0 License}

To Submit Your Article Click Here: Submit Article

DOI: $10.32474 /$ SJFN.2019.02.000135
11. Dodrill P, Hill RJ, Marshall J \& Ziviani J (2014) Features of feeding difficulty in children with autism spectrum disorder. International Journal of Speech-Language Pathology 16(2): 151-158.

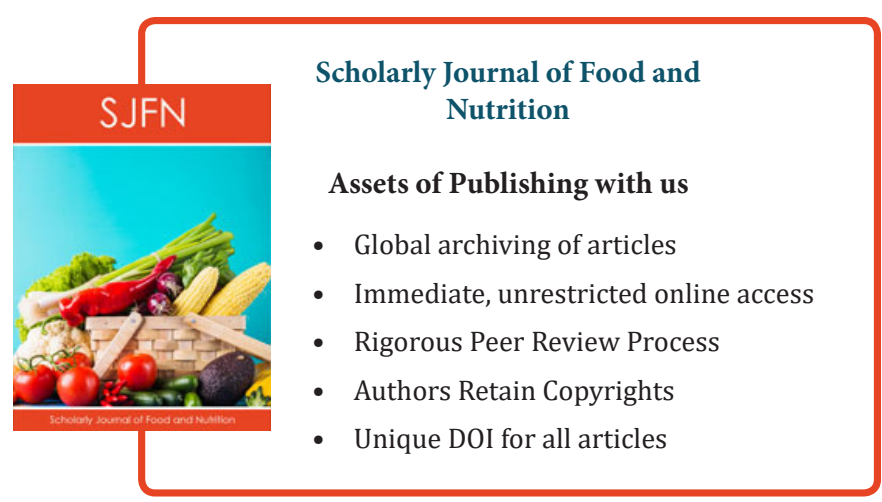

